\title{
Upaya Meningkatkan Daya Tarik Produk Makanan Dan Minuman Oleh-Oleh Di Tempat Destinasi Wisata Melalui Kajian Tanda Pada Desain Kemasan
}

\author{
Samodro \\ Program Studi Desain Komunikasi Visual, Universitas Pembangunan Jaya \\ samodro.margono@upj.ac.id
}

\begin{abstract}
The attractiveness of food and beverage products can be improved through the development of good packaging design. Efforts to increase attractiveness can be done through the development of packaging design that refers to the fulfillment of consumer needs through the fantasy or fantasy of a particular tourist destination area. The need is an effort to fulfill the need for memories or "memorabilia" as a reminder during the visit of the tour. Typical local cultural features are a reminder that can be a source of ideas in the development of packaging design of food and beverage products by-by. The characteristics of local culture can be the identity of a visual sign that can ultimately become an attraction on the packaging design view.
\end{abstract}

Keywords : attraction, packaging, local culture

\begin{abstract}
Abstrak : Daya tarik produk makanan dan minuman oleh-oleh dapat ditingkatkan melalui pengembangan desain kemasan yang baik. Upaya meningkatkan daya tarik dapat dilakukan melalui pengembangan desain kemasan yang mengacu pada pemenuhan kebutuhan konsumen yaitu melalui khayalan atau fantasi terhadap destinasi wisata daerah tertentu. Kebutuhan tersebut merupakan upaya pemenuhan kebutuhan akan kenangan atau "memorabilia" sebagai pengingat pada saat kunjung wisata tersebut. Ciri budaya lokal yang khas merupakan pengingat sehingga dapat menjadi sumber ide dalam pengembangan desain kemasan produk makanan dan minuman oleh-oleh. Ciri budaya lokal dapat menjadi identitas tanda visual yang pada akhirnya dapat menjadi daya tarik pada tampilan desain kemasan.
\end{abstract}

Kata Kunci : daya tarik, kemasan, budaya lokal

PENDAHULUAN

Latar Belakang

Budaya masyarakat sebagai latar belakang industri makanan dan minuman oleh-oleh

Pada awal sebelum industrialisasi di Nusantara, tradisi membuat makanan dan minuman telah dilakukan oleh kaum wanita dalam kegiatan rumah tangga mereka. Mereka membuat makanan dan minuman sebagai kegiatan untuk memenuhi kebutuhan keluarga mereka. Tradisi membuat makanan dan minuman di Nusantara berkembang seiring pengaruh para pendatang dari China, Belanda, India dan Arab. Mereka datang ke Nusantara dengan mengenalkan cara-cara dan citarasa baru dalam membuat makanan dan minuman. Perkenalan budaya mereka dengan masyarakat lokal diawali pada daerah pesisir sebagai pertemuan awal setelah mereka melakukan pelayaran dari daerah asal mereka. Mereka mengenalkan budaya yang baru, misalnya bakmi, bakso, tahu dan lumpia. Pada interaksi tersebut dihasilkan proses akulturasi dan adaptasi budaya terutama pada makanan dan minuman disesuaikan dengan kebiasaan masyarakat lokal. Setelah beberapa abad kemudian proses tersebut berkembang 
hingga berlanjut pada kegiatan industrialisasi makanan dan minuman pada daerah-daerah yang menjadi tujuan wisata.

Munculnya industrialisasi makanan dan minuman disekitar destinasi wisata dimaksudkan guna memenuhi kebutuhan pasar, utamanya untuk memenuhi kebutuhan kuliner bagi pengunjung wisata. Makanan dan minuman yang dipasarkan ditempat destinasi wisata tertentu dimaksudkan untuk memenuhi kebutuhan "memorabilia atau sebagai pengingat atau kenang-kenangan" bagi pengunjung wisata.

Makanan dan minuman dapat disebut sebagai makanan dan minuman oleh-oleh karena memiliki ciri sebagai makanan dan minuman oleh-oleh. Ciri makanan dan minuman oleh oleh adalah (ciri tersebut dikembangkan dari ciri produk seni pariwisata, dalam penelitian R.M. Soedarsono (1999).

1. Makanan dan minuman oleh-oleh dapat menjadi pengingat terhadap destinasi wisata (memorabilia).

2. Bentuknya ringkas, mini dan praktis mudah dijinjing.

3. Murah harganya

4. Tidak sakral

5. Memiliki ciri citarasa yang khas.

Makanan dan minuman oleh-oleh merupakan produk yang ditawarkan kepada konsumen pariwisata. Menurut Philip Kotler dan Armstrong (2000) "produk adalah segala sesuatu yang dapat ditawarkan ke pasar untuk mendapat perhatian, dibeli, dipergunakan, atau dikonsumsi dan yang dapat memuaskan keinginan atau kebutuhan." Makanan dan minuman oleh-oleh merupakan produk barang yang ditawarkan kepada konsumen pengunjung wisata. Pada hasil penelitian Boyne, Williams, \& Hall, (2002) menunjukkan bahwa pengunjung wisata di Inggris menghabiskan hampir $40 \%$ dari anggaran mereka pada makanan saat bepergian (dalam tesis Rose Steinmetz 2010). Didalam persaingan pasar produk makanan dan minuman oleh-oleh, aspek kemasan makanan dan minuman memegang peranan penting agar produk produk dapat diterima pasar. Oleh karena itu, desain kemasan produk makanan oleholeh harus diupayakan dapat menarik para konsumen. Upaya meningkatkan daya tarik produk kemasan oleh-oleh dapat dilakukan dengan meningkatkan daya tarik kemasan melalui tampilan visualnya dengan memanfaatkan ciri visual budaya lokal mereka. Ciri visual budaya lokal merupakan citra visual yang dapat menjadi ide kreatif guna memenuhi kebutuhan dan selera akan khayalan atau fantasi pengunjung wisata. Makanan dan minuman oleh-oleh merupakan produk "memorabilia atau sebagai pengingat atau kenangkenangan sehingga harus menampilkan ciri visual budaya lokal sebagai upaya untuk menimbulkan daya tarik konsumen.

Menurut Philip Kotler, keberhasilan suatu produk di pasaran ditentukan oleh diterima tidaknya produk oleh pasar. Artinya, produk yang tidak sesuai dengan kebutuhan dan keinginan pasar akan ditinggalkan. Produk yang tidak menarik tampilan visualnya akan diabaikan konsumen. Oleh karena itu perencanaan (pengembangan) kemasan produk makanan dan minuman oleh-oleh harus diupayakan menarik dan mampu memenuhi kebutuhan konsumen. Salah satu upaya untuk menarik perhatian konsumen maka kemasan produk makanan dan minuman oleh-oleh harus didesain menarik.

Pengemasan produk makanan dan minuman oleh-oleh bertujuan untuk:

a. Menjaga produk pangan agar tetap bersih, terlindung dari kotoran dan kontaminasi.

b. Menjaga produk pangan dari kerusakan fisik, perubahan kadar air dan pengaruh sinar matahari.

c. Memudahkan dalam membuka/menutup, memudahkan dalam penanganan, pengangkutan dan distribusi.

d. Menyeragamkan produk pangan dalam ukuran, bentuk dan bobot yang sesuai dengan standar yang ada. 
e. Menampakkan identifikasi, informasi, daya tarik dan tampilan yang jelas dari bahan pangan yang dikemas sehingga dapat membantu promosi/penjualan. Kemasan harus menarik sehingga dapat mempengaruhi perilaku pembelian konsumen.

f. Memberikan informasi melalui sistem labelling, bagaimana cara penggunaan produk, tanggal kadaluarsa dan lainlain.

Aspek tanda visual yang berlatar belakang budaya lokal pada desain kemasan produk makanan dan minuman oleh-oleh dimaksudkan agar terjadi relasi tanda antara objek tanda dan maknanya. Relasi tersebut dapat dibangun melalui aspek tanda pada tampilan visual kemasan dengan budaya masyarakat yang menjadi latar budaya masyarakat yang memproduksi tanda tersebut. Tanda visual tersebut dimaksudkan untuk berkomunikasi dengan sasaran yang berisi pesan-pesan. Charles Sanders Peirce (1839-1914) berkeyakinan bahwa manusia berpikir dalam tanda. Secara harfiah dijelaskan bahwa manusia hanya berpikir dalam tanda. Di samping itu ia juga melihat tanda sebagai unsur dalam komunikasi ,dalam Aart Van Zoest (1993). Latar budaya merupakan ideologi yang berkembang dan digunakan dalam penggunaan tanda. Konsepsi tanda dan latar budaya tersebut menurut Umberto Eco, perilaku manusia yang mengisyaratkan sinyal dalam hal tertentu perilaku itu dapat diketahuinya latar budaya pelaku karena perilakunya mempunyai denotasi yang jelas. Oleh karena itu didalam melakukan interpretasi terhadap tanda tersebut, pengamat harus memahami latar budaya, yakni konvensi budaya masyarakat pendukung tanda tersebut.

Di dalam pembahasan mengenai tanda pada visual kemasan produk makanan dan minuman oleh-oleh tersebut, maka digunakan pisau bedah dari Charles Sanders Peirce yang menyebut latar budaya merupakan keseluruhan dari peraturan, perjanjian, dan kebiasaan yang dilembagakan yang kita sebut sebagai kode. Latar budaya merupakan ideologi yang berkembang dan digunakan dalam melakukan pemaknaan terhadap tanda visual kemasan. Konsepsi tanda dan latar budayanya menurut Umberto Eco merupakan perilaku manusia yang mengisyaratkan sinyal, dalam hal tertentu maka perilaku itu dapat diketahui latar budayanya karena perilakunya mempunyai denotasi yang jelas.

Pada tulisan ini dijelaskan mengenai penggunaan tanda visual berciri budaya lokal pada tampilan kemasan untuk peningkatan nilai tambah produk makanan dan minuman oleh-oleh. Upaya kreatif tersebut merupakan cara yang dimaksudkan untuk meningkatkan nilai tambah kemasan melalui tanda visual yang dapat memenuhi kebutuhan "memorabilia atau sebagai pengingat atau kenang-kenangan pada kunjungan pada sebuah destinasi wisata. Didalam tulisan ini ditampilkan beberapa kasus pengemasan dari beberapa daerah destinasi wisata di Indonesia sebagai bahan kajian.

\section{Permasalahan}

Permasalahan dalam pengemasan produk makanan dan minuman oleh-oleh di tempat tujuan wisata masih dihadapkan pada kendala pengemasan produk yang tidak memiliki daya pikat pasar. Kajian pada tulisan ini dimaksudkan untuk menguak makna beberapa tampilan kemasan yang menggunakan tanda visual kemasan yang berciri budaya lokal untuk memenuhi kebutuhan "memorabilia atau sebagai pengingat atau kenang-kenangan " bagi pengunjung wisata.

Aspek tanda visual yang berciri budaya lokal pada kemasan produk oleh-oleh dikaji maknanya sebagai daya tarik wisata pada tampilan kemasan.

\section{Tujuan Penulisan}

Tulisan ini bertujuan untuk memberikan telaah literatur mengenai aspek tanda visual pada pengemasan 
produk makanan dan minuman oleh-oleh dengan ciri visual budaya lokal yang memberi dampak untuk menarik konsumen. Hal-hal yang dibahas dalam tulisan ini antara lain mengenai aspek tanda visual pada desain kemasan yang mengacu pada ide-ide kreatif yang bersumber pada ciri visual budaya lokal. Pemanfaatan citra visual budaya lokal pada aspek tanda dikaji guna menganalisa nilai tambah dan daya tarik kemasan produk makanan dan minuman oleh-oleh.

\section{Manfaat}

Penulisan ini akan memberi manfaat dalam beberapa aspek sebagai berikut:

1. Menunjukan kepada pelaku usaha industri makanan dan minuman oleholeh dan desainer tentang sumbersumber idea atau konsep yang bisa dimanfaatkan dalam penciptaan tampilan desain kemasan yang berdaya saing melalui penggalian terhadap unsur-unsur visual budaya lokal.

2. Sebagai salah satu upaya solusi atau strategi kreatif dalam pengembangan kemasan melalui pemanfaatan ciri visual budaya lokal sebagai upaya dalam memikat konsumen.

3. Mengungkap makna tanda visual pada kemasan, sebagai salah satu sumber referensi dalam pengembangan kemasan produk makanan dan minuman oleh-oleh.

4. Mendukung pelestarian budaya lokal guna dimanfaatkan dalam tampilan desain kemasan produk makanan dan minuman oleh-oleh yang akan dipublikasikan secara luas, terutama untuk mempromosikan merek produk lokal.

\section{KAJIAN PUSTAKA \\ Tinjauan Kemasan}

Kemasan merupakan bagian dari kegiatan promosi yang dimaksudkan untuk mendukung program pemasaran, proses penjualan dan proses pengiriman. Kemasan adalah alat komunikasi pemasaran dan merupakan 'alat pendongkrak' nilai tambah, sehingga memiliki daya saing. Berdasarkan hasil survey, $80 \%$ pengunjung pasar modern membeli sesuatu secara spontan karena melihat kemasan (label) yang sangat menarik, dalam Thomas Ghozali (2016) Label merupakan ujung tombak dari kemasan, karena bagian tersebut yang pertama kali dilihat lebih (fokus) oleh pengunjung.

Desain kemasan bertujuan untuk :

1. memberikan kemudahan dan kepuasan konsumen,

2. melindungi kualitas produk agar tetap dalam kondisi prima,

3. menampilkan identitas merek dan produk,

4. membangun citra merek dan produk,

5. alat komunikasi dan kompetisi pasar secara visual.

Adapun fungsi utama kemasan adalah

1. mempengaruhi dan membujuk konsumen,

2. mempengaruhi tingkah-laku konsumen,

3. menawarkan kepercayaan kepada konsumen,

4. 'memaksa' konsumen untuk melihat kemasan,

5. mendorong konsumen untuk segera membeli,

6. meningkatkan nilai tambah.

Kotler dan Amstrong (2012), mendefinisikan "packaging involves designing and producing the container or wrapper for a product" yang artinya adalah proses kemasan melibatkan kegiatan mendesain dan memproduksi. Fungsi utama dari kemasan sendiri yaitu untuk melindungi produk agar produk tetap terjaga kualitasnya.

Tampilan desain kemasan produk makanan dan minuman oleh-oleh yang baik akan mempengaruhi keputusan konsumen membeli. Produk makanan dan minuman oleh-oleh merupakan cendera mata yang dibutuhkan saat seseorang mengunjungi suatu daerah wisata. Cendera mata merupakan tanda yang memiliki relasi 
makna dengan destinasi wisata. Dalam bahasa Indonesia, istilah tersebut kadang disinonimkan dengan oleh-oleh, suvenir, tanda mata, atau kenang-kenangan. Cendera mata merupakan produk wisata yang menjadi bagian guna memenuhi kebutuhan "memorabilia atau sebagai pengingat atau kenang-kenangan pada saat seseorang berkunjung ke destinasi wisata.

\section{Produk Pariwisata}

Produk makanan dan minuman oleh-oleh merupakan bagian dari produk wisata yang berfungsi pula sebagai media yang dimaksudkan untuk mengkomunikasikan citra positif suatu daerah tujuan wisata. Produk makanan dan minuman oleh-oleh sebagai produk cendera mata memiliki fungsi yang strategis guna membangun loyalitas merek daerah (destination brand).

Merek daerah (destination brand) didefinisikan sebagai aktivitas pemasaran untuk mempromosikan citra positif suatu daerah tujuan wisata demi. Citra positif tersebut dapat dibangun dari citra positif produk makanan dan minuman oleh-oleh. Bisnis pariwisata identik dengan citra (image) sehingga citra harus dikembangkan ke arah yang positif untuk menarik konsumen.. Sebagai sebuah contoh: Yogyakarta dikenal sebagai daerah tujuan wisata yang dikenal sebagai Kota Gudeg. Perilaku konsumen yang mengunjungi Yogyakarta maka tidak lengkap bila tidak mengunjungi sentra industri gudeg di daerah Wijilan, Yogyakarta. Merek produk makanan oleh-oleh yang khas adalah Gudeg Yu Djum atau Gudeg Bu Tjitro.

Tujuan dari pemberian merek untuk suatu daerah adalah untuk antara lain: mengembangkan citra yang jelas dan spesifik yang mampu membedakan daerah tersebut dengan daerah lain. Destination branding adalah usaha merubah persepsi seorang terhadap suatu tempat atau tujuan termasuk melihat perbedaan sebuah tempat lainnya untuk dipilih sebagai tujuan wisata. Persepsi terhadap citra daerah tujuan wisata dipengaruhi kepuasan konsumen sehingga menumbuhkan loyalitas yang mendorong niat untuk mengunjungi lokasi terkait diwaktu yang akan datang. Pengalaman positif yang tak terlupakan yang diperoleh selama berwisata tersebut dapat dipuaskan melalui produk-produk wisata yang berkualitas salah satunya produk makanan dan minuman oleh-oleh dengan kemasan yang didesain menarik.

Citra terhadap destinasi dihasilkan dari kesatuan dari daya tarik destinasi wisata, fasilitas dari destinasi wisata dan kemudahan dari destinasi wisata. Ketiga unsur tersebut membentuk suatu citra produk pariwisata yang dapat ditawarkan kepada konsumen. Produk pariwisata merupakan seperangkat unsur-unsur yang membentuk suatu paket pariwisata yakni

1. Daya tarik objek wisata

2. Jasa Travel agent dan tour operator

3. Jasa transportasi

4. Jasa Pelayanan akomodasi

5. Jasa produk souvenir, pelayanan cinderamata dan makanan dan minuman oleh-oleh.

6. Jasa perusahan pendukung lainnya.

Seorang jurnalis dan kolomnis CNN, dalam Forum Budaya Dunia (World Culture Forum 2013) di Nusa Dua, Bali, Fareed Zakaria, menyampaikan pendapatnya bahwa era globalisasi, kultur dunia barat masuk keseluruh penjuru dunia. Kondisi ini, disisi lain mendorong penduduk penduduk lokal untuk menguatkan kembali budaya mereka. (Kompas, 26 November 2013).

Selanjutnya ia menyampaikan, tradisi lokal bukan mempertahankan aspek masa lalu (kecenderungan "jadul/kuno"), tetapi bersandingan dengan masa depan. Aspek tanda pada budaya lokal yang beraneka ragam di Indonesia sangat potensial guna memperkaya pembangunan ekonomi melalui sektor pariwisata khususnya pada citra kuliner makanan oleh oleh. Citra tersebut dapat ditampilkan pada kemasan produk makanan dan minuman oleh-oleh. 


\section{METODOLOGI PENELITIAN}

Pada tulisan ini observasi obyek desain kemasan dilakukan berdasarkan sudut pandang peneliti dengan memakai metode penelitian kualitatif. Langkah awal dari metodologi penelitian ini, yaitu observasi. observasi adalah studi yang disengaja dan sistematis tentang fenomena sosial dan gejala-gejala psikis dengan jalan pengamatan dan pencatatan. Istilah observasi diturunkan dari bahasa latin yang berarti "melihat" dan "memperhatikan".

Istilah observasi diarahkan pada kegiatan memperhatikan secara akurat, mencatat fenomena yang muncul, dan mempertimbangkan hubungan antar aspek dalam fenomena tersebut.

Didalam pengamatan aspek tanda visual pada tampilan kemasan makanan dan minuman oleh-oleh maka penulis menilai kekuatan pesan yang akan disampaikan pada tampilan visual yang dapat meningkatkan daya tarik melalui pesan memorabilia kepada konsumen. Beberapa kemasan diobservasi berdasarkan dua aspek. Aspek pertama berdasarkan identifikasi sifat fisik pada desain kemasan yang terkait dengan tanda yang menampilkan ciri visual budaya lokal mereka. Kedua mengidentifikasikan berdasarkan kekuatan pesan yang disampaikan melalui elemen-elemen tanda visual tersebut yang terkait dengan pesan menyampaikan citra budaya lokal mereka, terkait untuk membangun citra memorabilia. Intrepetasi tanda didasari pada aspek-aspek budaya lokal yang terkait dengan pencitraan daerah destinasi wisata dan keterkaitan dengan merek daerah (destination branding).

\section{HASIL PENELITIAN DAN ANALISIS}

Daya tarik kemasan harus dapat meningkatkan nilai tambah (value added). Daya tarik pada tampilan kemasan dapat ditampilkan untuk meyakinkan konsumen bahwa produk tersebut memang sesuai dengan kebutuhan dan keinginan konsumen. Aspek visual kemasan memegang peranan yang sangat penting dalam suksesnya proses penjualan.. Tampilan visual kemasan berfungsi dalam mempengaruhi dan membujuk konsumen sehingga membeli produk tersebut.

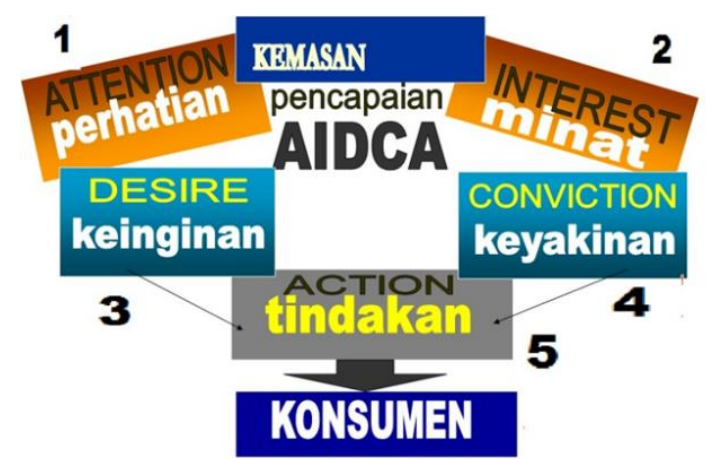

Gambar 1. Model AIDCA adalah formula yang acap digunakan untuk analisa dan acuan dalam perencanaan sebuah komunikasi visual.

Disamping itu, tampilan kemasan sebagai alat komunikasi visual menjadi media yang efektif dalam menyampaikan pesan-pesan yang terkait dengan citra budaya lokal sebuah destinasi wisata. Citra visual budaya lokal yang menjadi ciri sebuah destinasi wisata (memorabilia) dapat ditampilkan dalam visual kemasan produk makanan dan minuman oleh-oleh. Pemahaman terhadap makna tanda yang melatar belakangi tanda tersebut dibuat merupakan kunci dalam memahami tanda yang disebut dengan kode. Konsumen dapat memahami makna tanda tersebut karena asumsinya konsumem memahami kodenya. Didalam benak pikiran konsumen maka pemahaman tersebut diharapkan dapat untuk membangkitkan kesan memorabilia.

Wisata berbasis budaya dengan budaya lokal yang khas menjadi sebuah trend sehingga dapat dicermati sebagai bagian dari upaya ide kreatif dalam perancangan kemasan. Ide kreatif dapat dilakukan dengan memanfaatkan citra visual budaya lokal sebagai cara untuk menarik minat konsumen.

Didalam bahasan ini, penulis mengamati beberapa kemasan produk makanan dan minuman oleh-oleh yang dari 
kabupaten Kerinci, kabupaten Sukabumi, DI Yogyakarta, kab. Cilegon, kabupaten Banyumas(Sokaraja), dan kota Tangerang Selatan. Penulis mengamati beberapa kemasan produk makanan oleh-oleh pada sentra-sentra tersebut tidak dirancang matang guna memenuhi kebutuhan pengunjung wisata, yakni kebutuhan produk "memorabilia atau sebagai pengingat atau kenang-kenangan bagi para wisatawan.

Pada kajian ini aspek budaya lokal pada tampilan visual kemasan menjadi hal utama yang diamati karena faktor tersebut merupakam faktor utama yang menentukan dalam proses pembelian. Perilaku pembelian konsumen sebenarnya dipengaruhi oleh faktor-faktor budaya, sosial, pribadi, dan psikologis. Sedangkan faktor yang paling berpengaruh dan paling luas dan paling dalam adalah faktor budaya.

Menurut Kotler (1995:203): Faktorfaktor yang mempengaruhi perilaku konsumen (perilaku pembelian) adalah kebudayaan, faktor sosial, pribadi, psikologis. Sebagian faktor-faktor tersebut tidak diperhatikan oleh pemasar tetapi sebenarnya harus diperhitungkan untuk mengetahui seberapa jauh faktor-faktor perilaku konsumen tersebut mempengaruhi pembelian konsumen.

\section{Produk Tanda Pada Kemasan Oleh- Oleh}

Didalam upaya untuk memahami tanda visual desain kemasan produk makanan dan minuman oleh-oleh maka perlu dipahami bahwa proses membuatan makanan dan minuman oleh-oleh merupakan proses yang telah membudaya pada sekelompok masyarakat di Indonesia. Budaya merupakan ketrampilan suatu kelompok dalam masyarakat untuk mengenali dan mengintrepetasikan, serta memproduksi tanda dengan cara yang sama.

Budaya dapat diartikan sebagai suatu keseluruhan kebiasaan semiotis yang saling berkait. Kebiasaan tersebut memberikan semacam efesiensi kepada dunia tempat segala sesuatu dapat merupakan tanda. Charles Sanders Peirce (1839-1914) dalam buku Aart van Zoest (1993) berkeyakinan bahwa manusia berpikir dalam tanda.

Secara harfiah dapat dijelaskan bahwa kita hanya berpikir dalam tanda. Di samping itu ia juga melihat tanda sebagai unsur dalam komunikasi. Artinya bahwa, bila dilihat dari produk budaya maka produk makanan dan minuman merupakan sebuah tanda. Sebagai sebuah tanda maka makanan dan minuman dapat diamati untuk dimaknai.

Didalam proses memaknai sebuah tanda visual pada kemasan makanan dan minuman maka dapat diketahui latar budaya masyarakat yang merupakan ideologi yang berkembang dan digunakan dalam penggunaan tanda tersebut. Tanda visual tersebut dapat dimaknai dengan cara yang berbeda-beda tergantung latar budaya pengamat tanda tersebut. Tanda visual dapat dimaknai tergantung konteks budaya masyarakat yang menyertainya. Oleh karena itu, didalam melakukan interpretasi terhadap tanda pada sebuah kebudayaan maka harus dipahami latar budaya, yakni konvensi budaya masyarakat pendukung tanda tersebut.

Charles Sanders Peirce yang menyebut latar budaya merupakan keseluruhan dari peraturan, perjanjian, dan kebiasaan yang dilembagakan yang kita sebut sebagai kode. Pemahaman terhadap kode menjadi penting karena dibeberapa lokasi sentra yang menjadi objek kajian terdapat keberagaman latar budaya yang menyertainya. 
Tabel 1. Skema Analisis Terhadap Beberapa Tampilan Pada Kemasan Produk Makanan Dan Minuman Oleh-Oleh

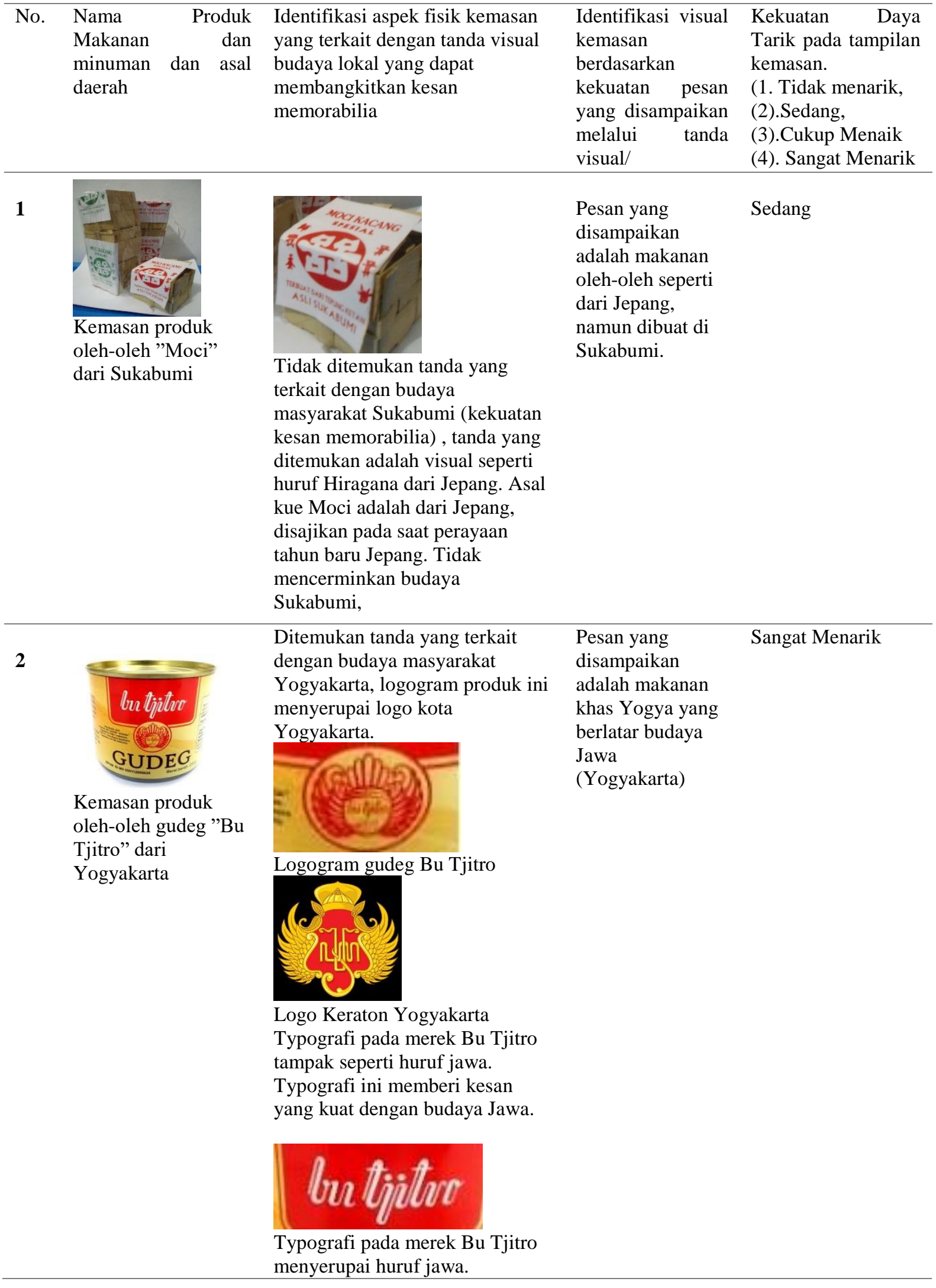




\begin{tabular}{|c|c|c|c|c|}
\hline No. & 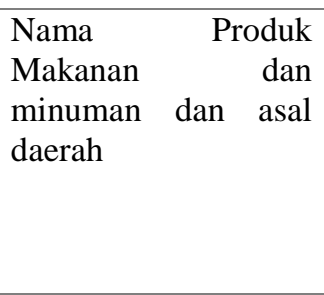 & $\begin{array}{l}\text { Identifikasi aspek fisik kemasan } \\
\text { yang terkait dengan tanda visual } \\
\text { budaya lokal yang dapat } \\
\text { membangkitkan kesan } \\
\text { memorabilia }\end{array}$ & $\begin{array}{l}\text { Identifikasi visual } \\
\text { kemasan } \\
\text { berdasarkan } \\
\text { kekuatan pesan } \\
\text { yang disampaikan } \\
\text { melalui tanda } \\
\text { visual/ }\end{array}$ & $\begin{array}{l}\text { Kekuatan Daya } \\
\text { Tarik pada tampilan } \\
\text { kemasan. } \\
\text { (1. Tidak menarik, } \\
\text { (2).Sedang, } \\
\text { (3).Cukup Menaik } \\
\text { (4). Sangat Menarik }\end{array}$ \\
\hline & & 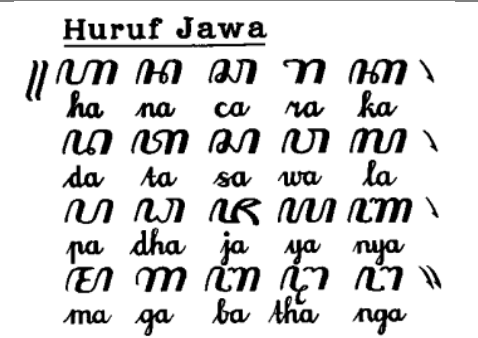 & & \\
\hline 3 & $\begin{array}{l}\text { Kemasan produk } \\
\text { oleh-oleh "Jahe } \\
\text { Merah" dari Cilegon } \\
\text { Banten }\end{array}$ & $\begin{array}{l}\text { Tidak ditemukan tanda visual } \\
\text { yang terkait dengan budaya } \\
\text { masyarakat Cilegon,Banten. }\end{array}$ & $\begin{array}{l}\text { Pesan yang } \\
\text { disampaikan } \\
\text { adalah minuman } \\
\text { yang bisa } \\
\text { disajikan santai } \\
\text { karena dibuat dari } \\
\text { jahe merah }\end{array}$ & Tidak Menarik \\
\hline 4 & $\begin{array}{l}\text { Kemasan produk } \\
\text { oleh-oleh"Koerintji- } \\
\text { ALFAFA" dari } \\
\text { Sungai Penuh, } \\
\text { Kabupaten Kerinci, } \\
\text { Prop. Jambi }\end{array}$ & 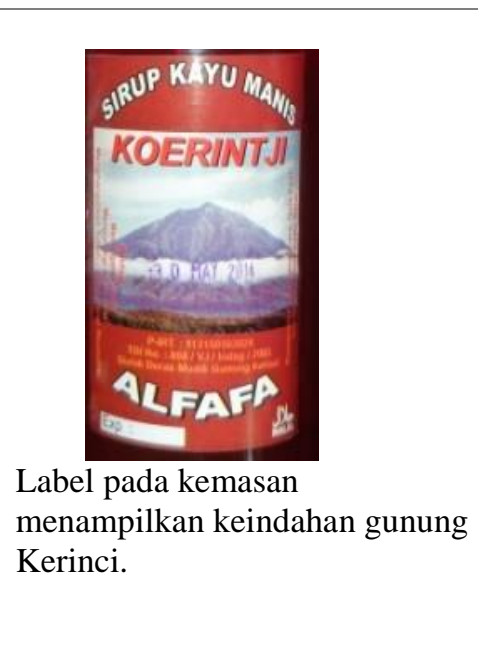 & $\begin{array}{l}\text { Pesan yang } \\
\text { disampaikan } \\
\text { adalah minuman } \\
\text { yang khas dari } \\
\text { Kabupaten } \\
\text { Kerinci, } \\
\text { dihasilkan dari } \\
\text { tanaman kayu } \\
\text { manis yang } \\
\text { tumbuh di } \\
\text { pegunungan } \\
\text { Kerici. Tampilan } \\
\text { visual tidak } \\
\text { menampilkan } \\
\text { budaya lokal yang } \\
\text { khas. }\end{array}$ & $\begin{array}{l}\text { Cukup menarik, } \\
\text { namun tidak } \\
\text { menampilkan } \\
\text { kekhasan budaya } \\
\text { Kerinci }\end{array}$ \\
\hline
\end{tabular}




\begin{tabular}{|c|c|c|c|c|}
\hline No. & $\begin{array}{lrr}\text { Nama } & \text { Produk } \\
\text { Makanan } & \text { dan } \\
\text { minuman } & \text { dan } & \text { asal } \\
\text { daerah } & & \end{array}$ & $\begin{array}{l}\text { Identifikasi aspek fisik kemasan } \\
\text { yang terkait dengan tanda visual } \\
\text { budaya lokal yang dapat } \\
\text { membangkitkan kesan } \\
\text { memorabilia }\end{array}$ & $\begin{array}{l}\text { Identifikasi visual } \\
\text { kemasan } \\
\text { berdasarkan } \\
\text { kekuatan pesan } \\
\text { yang disampaikan } \\
\text { melalui tanda } \\
\text { visual/ }\end{array}$ & $\begin{array}{l}\text { Kekuatan Daya } \\
\text { Tarik pada tampilan } \\
\text { kemasan. } \\
\text { (1. Tidak menarik, } \\
\text { (2).Sedang, } \\
\text { (3).Cukup Menaik } \\
\text { (4). Sangat Menarik }\end{array}$ \\
\hline 5 & $\begin{array}{l}\text { Kemasan produk } \\
\text { oleh-oleh " Gethuk } \\
\text { Goreng Janoko" dari } \\
\text { Sokaraja, Banyumas } \\
\text { Jawa Tengah. }\end{array}$ & $\begin{array}{l}\text { Ditemukan tanda visual yang } \\
\text { terkait dengan budaya masyarakat } \\
\text { Sokaraja, Banyumas. Logogram } \\
\text { bentuk wayang Janoko atau } \\
\text { Arjuna didunakan sebagai merek } \\
\text { dagang tersebut. Arjuna atau } \\
\text { Janoko merupakan tokoh idola } \\
\text { pada pertunjukan wayang selain } \\
\text { Bima. Tokoh ini menjadi idola } \\
\text { masyarakat Jawa pada bagian } \\
\text { Barat. Tokoh Janoko dikenal } \\
\text { tampan dan memiliki kesaktian } \\
\text { yang sangat dahsyat. }\end{array}$ & $\begin{array}{l}\text { Tata letak dan } \\
\text { tampilan visual } \\
\text { kurang menarik, } \\
\text { tokoh Janoko } \\
\text { tidak ditampilkan } \\
\text { dengan baik. }\end{array}$ & Cukup menarik. \\
\hline 6 & $\begin{array}{lr}\text { Kemasan } & \text { produk } \\
\text { oleh-oleh" } & \text { Bir } \\
\text { Plethok } & \text { Bang } \\
\text { Plethok" } & \text { dari } \\
\text { Tangerang } & \text { Selatan, } \\
\text { Banten } & \\
& \end{array}$ & $\begin{array}{l}\text { Bir Plethok awalnya adalah } \\
\text { bagian dari upaya masyarakat } \\
\text { lokal untuk melawan budaya } \\
\text { Barat (Belanda) secara kultural. } \\
\text { Orang-orang Betawi menolak bir } \\
\text { yang dikenalkan penjajah Belanda } \\
\text { karena mengandung alkohol dan } \\
\text { bisa membuat mabuk. Maka orang } \\
\text { Betawi membuat bir sendiri yang } \\
\text { dibuat dari rempah-rempah } \\
\text { sehingga bisa disebut minuman } \\
\text { Bir namun tidak memabukan } \\
\text { karena halal. Pada tampilan visual } \\
\text { kemasan ditampilkan gambar } \\
\text { Bang Jay sebagai produsen bir } \\
\text { plethok. }\end{array}$ & $\begin{array}{l}\text { Karakter Bang } \\
\text { Jay } \\
\text { Karakter Pitung } \\
\text { Betawi budaya } \\
\text { kuat }\end{array}$ & Sangat Menarik \\
\hline
\end{tabular}

\section{KESIMPULAN}

Daya tarik produk makanan dan minuman oleh-oleh dapat dicapai melalui perancangan desain kemasan yang baik. Desain kemasan yang baik adalah desain kemasan yang mampu menarik konsumen dan mendorong konsumen untuk melakukan proses pembelian. Daya tarik kemasan tersebut dapat dilakukan melalui rancangan desain yang kreatif, salah satunya dengan gagasan ide dengan menampilkan secara visual budaya lokal.

Upaya meningkatkan daya tarik konsumen pariwisata melalui desain 
kemasan produk oleh-oleh dapat dicapai dengan tampilan visual kemasan yang dapat memenuhi kebutuhan memorabilia, yakni sebagai pengingat atau kenang-kenangan pada kunjungan pada sebuah destinasi wisata. Budaya masyarakat lokal dapat ditampilkan secara visual untuk membangkitkan kesan memorabilia pengunjung wisata. Penulis melakukan kajian terhadap beberapa kemasan produk oleh-oleh di yang ditemukan di kabupaten Sukabumi,Yogyakarta,Cilegon, Kerinci, Banyumas, Tangerang Selatan.

Pada produk makanan dan minuman oleh-oleh tujuan pengemasan ditambahkan untuk membangun citra sebuah destinasi wisata (destination brand). Tujuan pengemasan disamping untuk mendorong penjualan adalah untuk membangun citra sebuah destinasi wisata. Citra positif suatu daerah tujuan wisata dapat dibangun melalui produk makanan dan minuman oleh-oleh yang berciri budaya lokal.

\section{DAFTAR PUSTAKA}

1. Dalam laporan penelitian tahun kedua, Soedarsono, R.M. "The Impact of Tourism on Indonesian Performing Arts, DirJen Pendidikan Tinggi, Depdikbud, 1999, hal.93.

2. Kotler, P., Manajemen Pemasaran, PT. Prenhallindo, Jakarta, 2000.
3. Boyne, Williams, \& Hall,. Culinary Tourism a Destination attraction : an Empirical Examination of The Destination's Food Image and Information Sources,2002. dalam http://digital.library.okstate.edu/etd/umi -okstate-1962.pdf.

4. Zoest, Van Aart, Semiotika -Tentang Tanda, Cara kerjanya dan Apa yang Kita Lakukan Dengannya, Jakarta: Yayasan Sumber Agung, 1993.

5. Dikatakan oleh Thomas Ghozali pelatihan Kemasan dan Label Makanan Olahan yang diadakan Edukadin Kadin Jateng bekerjasama dengan Balai Besar Pendidikan dan Pelatihan Ekspor Indonesia Dirjen Pengembangan Ekspor Nasional Kementrian Perdagangan RI (2016) dalam

https://bisnisukm.com/pelatihan-

kemasan-makanan-dan-label-produkkadin-jateng.html, 2016.

6. Kotler, Philip and Gary Armstrong, Prinsip-prinsip Pemasaran, Edisi13, Jilid 1, Jakarta, Erlangga, 2012.

7. Steinmetz, Rose, Food, Tourism and Destination Differentiation: The Case of Rotorua, New Zealand, A thesis submitted to the Auckland University of Technology in fulfillment of the requirements for the degree of Master of Philosophy (MPhil) 2010. 